\title{
RESEARCH OF TRAINING LOADS OF BASKETBALL PLAYERS
}

\author{
Victor Koryahin ${ }^{1 \mathrm{ABCDE}}$, Oksana Blavt ${ }^{1 \mathrm{ABCDE}}$, Volodymyr Prystynskyi ${ }^{2 \mathrm{ABCDE}}$, \\ Volodymyr Stadnyk ${ }^{1 \mathrm{ABCDE}}$ \\ ${ }^{1}$ Lviv Polytechnic National University \\ ${ }^{2}$ State Higher Educational Institution "Donbass State Pedagogical University" \\ Authors' Contribution: A - Study design; B - Data collection; C - Statistical analysis; D - Manuscript Preparation; E - Funds Collection
}

Corresponding Author: Oksana Blavt, E-mail: oksanablavt@ukr.net

Accepted for Publication: May 12, 2021

Published: June 25, 2021

DOI: 10.17309/tmfv.2021.2.02

\begin{abstract}
The study objective is to identify physiological indicators for the systematization of basketball players' special exercises and limit values of physiological indicators with sufficient "distinctive power" in each of the allocated training load ranges.

Materials and methods. The study used empirical methods of measuring heart rate during competitions, pulmonary ventilation values, $\mathrm{O}_{2}$ consumption during physical work, $\mathrm{O}_{2}$-debt, "excess" $\mathrm{CO}_{2}$ emissions and individual pulse rates, methods of mathematical statistics.

Results. Relationships between the level of physical activity and physiological shifts in the body of basketball players have been established. It is revealed that indicators of pulmonary ventilation can be used to control the training effect of aerobic exercise. Exercises of anaerobic glycolytic orientation have been shown to have the most pronounced effect on the body of basketball players. There are certain mean and limit values for different physiological parameters, characteristic of different ranges of training loads.

Conclusions. It is established that in assessing the urgent training effect of special exercises of basketball players, different physiological indicators have different "distinguishing power". Based on the results of the study, it is proposed to systematize the special exercises of basketball players according to the ranges of training loads by the nature of their training effect.
\end{abstract}

Keywords: basketball, special exercises, evaluation, load, training effect, power difference.

\section{Introduction}

Problem statement. The progress of the sport of excellence is related to the justification of the elements of the system of athletes and its orientation to the sports result (Nelsen, 2015). The training of high-end basketball players is a complex, dynamic pedagogical process based on a deep understanding of the causes of the factors that determine its effectiveness under the direct influence of changes occurring in basketball (Raiola, Altavilla, Tafuri, \& Lipoma, 2016; Doroshenko, Sushko, Koryahin, Pityn, Tkalich, \& Blavt, 2019). This requires mastery of a complex of knowledge of the latest scientific achievements in the training of high-skilled athletes (Backman, Danielson, 2011; Hoare, 2000).

One of the most important prerequisites for effective management of the training process is the creation of a unified system of accounting training loads. Such accounting can be implemented by systematizing physical exercises used

(C) Koryahin, V., Blavt, O., Prystynskyi, V., Stadnyk, V., 2021. as training aids, on the basis of any particular attribute (Gonzalo-Skok, Tous-Fajardo, Valero-Campo, Berzosa, Bataller, Arjol-Serrano, \& Mendez-Villanueva, 2017; Karpowicz \& Karpowicz, 2013). So far, the question of the applicability of systematisation to the special means used in the preparation of basketball players remains relevant.

Analysis of recent research and publications. To date, the developed systematization of special exercises in basketball was in most cases based on assessments of the nature of the technical and tactical tasks and their degree of compliance with the specifics of basketball players' game activity (Asadi, Saez de Villarreal, \& Arazi, 2015; Ben Abdelkrim, Castagna, El Fazaa, \& El Ati, 2010). Another approach and systematization of special exercises of basketball players is based on the account of the physiological impact of loads on the body of athletes (Beaver, Wasserman, \& Whipp, 1986; Ciuti, Marcello, Macis, Onnis, Solinas, \& Lai, 2009).

The effectiveness of the system of long-term training of basketball players is constantly in the center of attention of 
specialists (Aiken, Fairbrother, \& Post, 2012; Montgomery, Pyne, \& Minahan, 2010). Achieving the ultimate goals - the preparation of a highly qualified reserve depends crucially on the special training tools used in the preparation of the basketball players (Backman \& Danielson, 2011; Tyshchenko, Hnatchuk, Pasichnyk, Bubela, \& Semeryak, 2018).

Based on the literature, two fundamental approaches can be used to establish the training load gradations in basketball:

- systematization of exercises taking into account the characteristics of physical activity (GonzaloSkok, Sánchez-Sabaté, Izquierdo-Lupón, \& Sáez de Villarreal, 2019; Erčulj, Blas, \& Bračič, 2010; Karpowicz \& Karpowicz, 2013);

- gradation of loads on the basis of taking into account the physiological changes that occur in the body under the influence of physical activity (Ben Abdelkrim, El Fazaa, \& El Ati, 2007; Conlee, McGown, Fisher, Dalsky, \& Robinson, 2017).

It has been proven that in basketball, it is not always possible to accurately determine exercise parameters (Anastasiadis, 2006). There is an opinion that in the systematization and normalization of training loads, the account of the response of the physiological reactions of the body is considered more appropriate (Sallet, Perrier, Ferret, Vitelli, \& Baverel, 2005; Tomlin \& Wenger, 2002).

However, the question of the applicability of physiological criteria-based systematization to the special means used in the preparation of basketball players is still unresolved.

Purpose of the research is to identify physiological indicators for the systematization of basketball players' special exercises and limit values of physiological indicators with sufficient "distinctive power" in each of the allocated training load ranges.

\section{Materials and methods}

\section{Study Participants}

The study involved 18 professional basketball players who took part in the championship of Ukraine.

\section{Study organization}

The study of the heart rate during competitions was conducted by means of the method of continuous automatic registration using the multichannel system (Koryagin \& Blavt, 2019). This allowed determine the maximum mean pulse rate during the game, as well as the maximum pulse rate total during the game and during the recovery.

The level of pulmonary ventilation was determined by way of collecting expired air into Douglas bags with the subsequent measurement of the volume of the air contained in the bag using a laboratory gas meter (Beaver, Wasserman, \& Whipp, 1986). The accuracy of the gas meter readings was checked by passing a precisely measured volume of air through it. When passing 100 litres of control volume of air, the deviation in the gas meter readings in 35 measurements amounted to an average of $0.84 \pm 0.13$ (MacDougall, Wenger, \& Green, 2017).

The air collection was carried out using a breathing mask and a low-resistance valve $(6 \mathrm{~mm} \mathrm{Hg})$ at the air flow velocity of $300 \mathrm{l} / \mathrm{min}$. The diameter of the air-conducting paths was $4.5 \mathrm{~cm}$.
All parameters of ventilation of lungs were brought to the conditions of the body temperature, atmospheric pressure and saturation with water vapour.

The percent composition was determined by way of analyzing the samples using the gas analyzers Spirolit and METAMAX that are capable of recording the concentration of $\mathrm{O}_{2}$ and $\mathrm{CO}_{2}$ in expired air.

The accuracy of the performed analyzes was controlled using duplicate determinations of the gas composition of the same sample. The total error in the measurements of $\mathrm{O}_{2}$ consumption and $\mathrm{CO}_{2}$ release during competitive activity made up $0.9 \%$.

In the recovery period, air samples were taken for 32 minutes. At the same time, the sportsmen's heart rate was also recorded during the recovery period.

All the indicators of the heart rate, as well as the level of $\mathrm{O}_{2}$ consumption, total $\mathrm{O}_{2}$, the level of $\mathrm{CO}_{2}$ release and oxygen pulse rate were calculated according to the method described in the works (Volkov, 1986; Zankovets, 2016).

\section{Statistical Analysis}

Mathematical methods (Vincent, 2005) of information delivery for statistical analysis of experimental data were applied in two stages. The first stage is the stage of aggregation and grouping of the received statistical material. At this stage, they have summarized and systematized the empirical data of the experimental study, moving from their qualitative characteristics to quantitative expression. This was implemented by descriptive statistics methods and represented using graphical methods. The second stage is the stage of responding to the task of the research objective by evaluating the final results. For this purpose, a regression analysis of the search for models of the relationship between two quantities, expressed in the regression function, was applied. Analytical statistics methods have been used to process statistics and formulate conclusions.

\section{Results}

First of all, it should be noted that according to empirical data, physiological indicators by which it is possible to evaluate the urgent training effect of special exercises of basketball players, have different "distinctive power" (Anastasiadis, 2006; Beaver, Wasserman, \& Whipp, 1986). With the change of physical activity parameters, each indicator changes specifically until it reaches the limit values. Above these values, physiological indicators become insensitive to the increasing impact of physical activity (Conlee, McGown, Fisher, Dalsky, \& Robinson, 2017; Yeager \& Karsten, 2016).

The simplest way to establish the "distinctive power" of individual physiological indicators is to analyze the regression dependencies that relate these parameters to the parameters of the leading physiological functions (Doroshenko, Sushko, Koryahin, Pityn, Tkalich, \& Blavt, 2019). Examples of such dependencies are shown graphically (Fig. 1-3).

In Fig. 1 presents the dependence of the two most important indicators of aerobic and anaerobic metabolism - the level of $\mathrm{O}_{2}$ consumption and the rate of release of "excess" $\mathrm{CO}_{2}$. The regression of these indices can be approximated by an exponential dependence. Only when performing moderate exercises, the energy request of which does not exceed the 
level of $\mathrm{O}_{2}$ consumption of $2.3 \mathrm{l} / \mathrm{min}$, is there a linear proportion between aerobic metabolism and excess $\mathrm{CO}_{2}$ evolution in anaerobic lactic acid production.

With increasing exercise power, the level of anaerobic metabolism, estimated by the rate of release of "excess" $\mathrm{CO}_{2}$, increases much faster than the intensity of aerobic processes increases. The sections of the graph, indicated by different hatching, correspond to the values of the measured indicators relating to the ranges of training loads of different orientation. Based on the established relationships between the indicators of physical activity and physiological shifts in the body, we attributed all the studied exercises to 4 ranges of training loads:

- loads of mainly aerobic orientation;

- loads of mixed aerobic-anaerobic effects;

- loads of anaerobic glycolytic orientation;

- loads of anaerobic alactate action (Anastasiadis, 2006; Ingebrigtsen, Jeffreys, Rodahl, 2013; Volkov, 1986).

As can be seen in the regression graph (Fig. 1), the values of the $\mathrm{O}_{2}$-consumption and $\mathrm{Ex}-\mathrm{CO}_{2}$ indicators related to the different exercises are clearly grouped on the selected sections of the regression field. Based on this grouping of indicators characterizing the urgent training effect of exercises of different orientation, it is possible to determine the boundary values of physiological indicators inherent in the distant ranges of training loads.

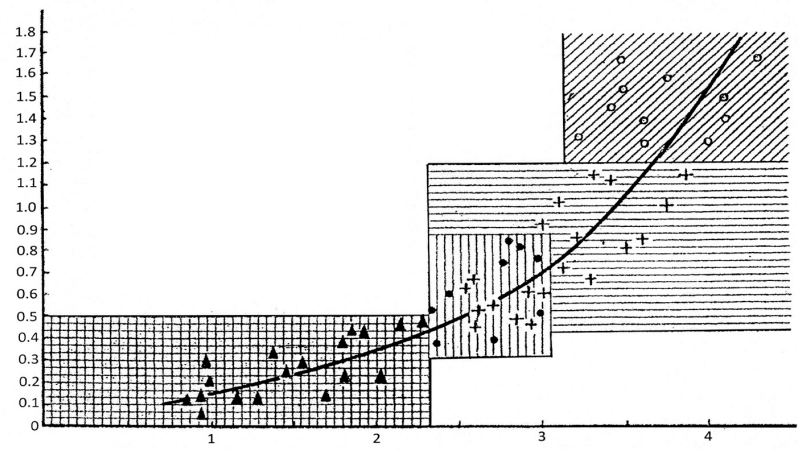

Fig. 1. Regression between indicators of "non-metabolic excess" of $\mathrm{CO}_{2}$ and $\mathrm{O}_{2}$-consumption at performance of special exercises of basketball players. In the ordinate - the level of release of "excess"

$\mathrm{CO}_{2}, 1 / \mathrm{min}$. Symbols: 1 - exercises of aerobic orientation, 2 aerobic-anaerobic; 3 - anaerobic alactate; 4 - anaerobic glycolytic orientation

Setting these values in the future can be used to control the training process. For example, from the analysis of the given regression dependence it follows that when performing exercises mainly aerobic orientation values of the rate of excess $\mathrm{CO}_{2}$ emission should not exceed $0.5 \mathrm{l} / \mathrm{min}$, and the level of $\mathrm{O}_{2}$ consumption should not be higher than $2.3 \mathrm{l} / \mathrm{min}$. When performing aerobic-anaerobic exercise, the change in the rate of $\mathrm{CO}_{2}$ evolution is limited by the range of values from 0.5 to $1.21 / \mathrm{min}$, and the measurement of the level of $\mathrm{O}_{2}$ consumption - from $2.3 \mathrm{l} / \mathrm{min}$ to the maximum values of $\mathrm{O}_{2}$. Exercise of alactate anaerobic orientation is characterized by the following limits of variation for the rate of excess $\mathrm{CO}_{2}$ evolution - from 0.35 to $0.8 \mathrm{l} / \mathrm{min}$, for the level of $\mathrm{O}_{2}$ consumption - from 2.3 to $3.1 \mathrm{l} / \mathrm{min}$. Exercise of anaerobic glycolytic orientation exercises is accompanied by the release of excess $\mathrm{CO}_{2}$ in sizes from $1.2 \mathrm{l} / \mathrm{min}$ to maximum values, and the level of $\mathrm{O}_{2}$ consumption - in the range from $3.2 \mathrm{l} / \mathrm{min}$ to values of maximum $\mathrm{O}_{2}$.

In Figure 2 presents regression graphs of the $\mathrm{O}_{2}$ consumption level indicator and the indicators evaluating the intensity of anaerobic tissue changes. At the top of the change in the level of $\mathrm{O}_{2}$ consumption are compared with the increase in the rate of release of "excess" $\mathrm{CO}_{2}$, characterizing the relative power of the glycolytic process. It can be clearly seen here that changes in the $\mathrm{O}_{2}$ consumption are observed only in the range of glycolysis rate values, which do not exceed 50$70 \%$ of the maximum capacity of this anaerobic process. At higher values of the rate of anaerobic transformations in the body, the values of $\mathrm{O}_{2}$ consumption do not change. This suggests that for high-intensity exercise, where anaerobic processes are the main focus of exercise energy, the level of $\mathrm{O}_{2}$ consumption no longer has sufficient "distinctive power" and cannot be used in the exercise gradation.

This is confirmed by the data of the analysis of the dependence of the level of $\mathrm{O}_{2}$ consumption on the rate of formation of alactate $\mathrm{O}_{2}$ debt (Fig. 2.B). Here, the points related to exercise of alactate anaerobic orientation, strongly fall out of the total dependence established on the results of measurements of these indicators in other ranges of training loads. Changes in pulmonary ventilation indices, which estimate the size of $\mathrm{O}_{2}$ flow through the lungs, depending on the detected shifts of the basic parameters of aerobic and anaerobic metabolism, are presented in Fig. 3.
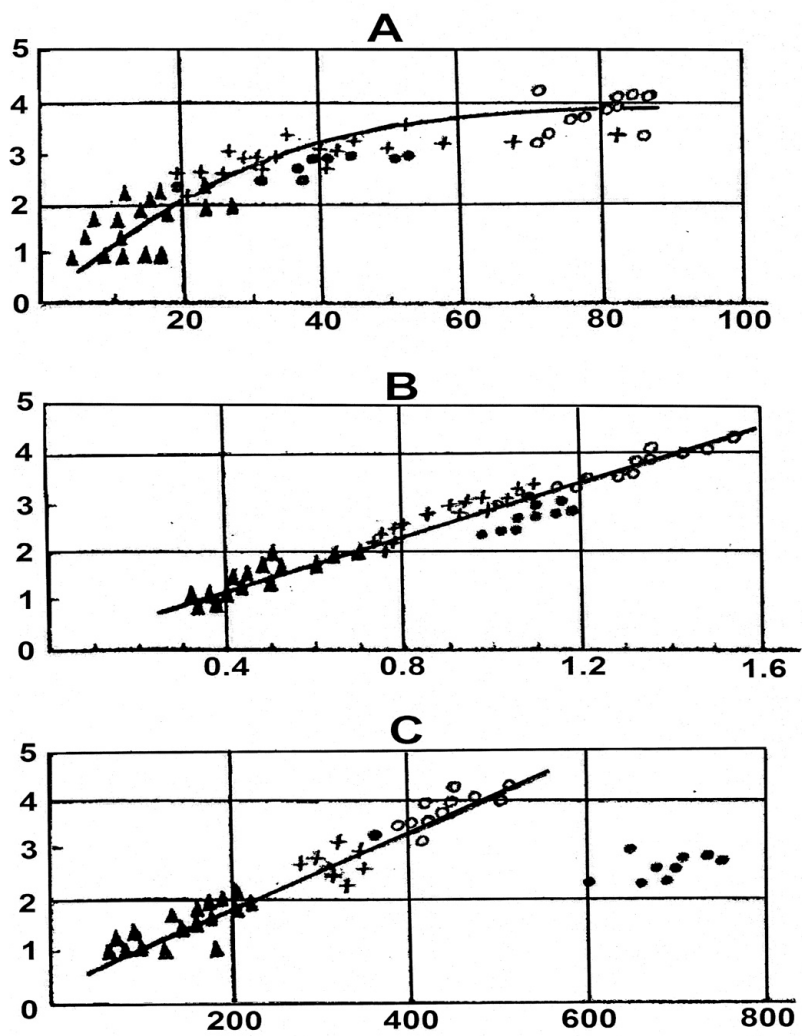

Fig. 2. Change of the $\mathrm{O}_{2}$ consumption indicator depending on the intensity of metabolic processes in the performance of special exercises of basketball players. A - Regressions of $\mathrm{O}_{2}$ consumption figures by level of anaerobic metabolism ( $\left.\mathrm{Ex} \mathrm{CO}_{2}, \% \max \right) ; \mathrm{B}$ - the rate of use of macroergies $(\sim \mathrm{P} / \mathrm{t}, \mathrm{M} / \mathrm{min}) ; \mathrm{C}$ - the rate of formation of alactate $\mathrm{O}_{2}$-debt $\left(\right.$ Alact. $\mathrm{O}_{2}$-debt/t ml/min). At the ordinate, $\mathrm{O}_{2}$ consumption, $1 / \mathrm{min}$. 
It can be seen that there is a linear relationship between pulmonary ventilation rate and aerobic process speed that covers all ranges of training loads. This suggests that the effects on systems responsible for oxygen transport are progressively increased by the stimulation of aerobic processes in tissues. Consequently, pulmonary ventilation indicators may well be used to control the training effects of aerobic exercise.

Based on the analysis of the relationship between the indicators of pulmonary ventilation and the rate of "excess" $\mathrm{CO}_{2}$ evolution, it is established that an increase in the rate of $\mathrm{O}_{2}$ intake through the lungs is detected only until the value of "excess" $\mathrm{CO}_{2}$ emission reaches $50 \%$ of the maximum. Changes in pulmonary ventilation depending on the rate of splitting of macroergs show a tendency to increase exponentially at high exercise powers. This can be regarded as an indication that the degree of metabolic activity of working muscles is the main factor in the regulation of external respiration during intense muscular work.

\section{Discussion}

Studying the different characteristics of physiological indicators to systematize the specific exercises of basketball players remains an important element in obtaining informa-

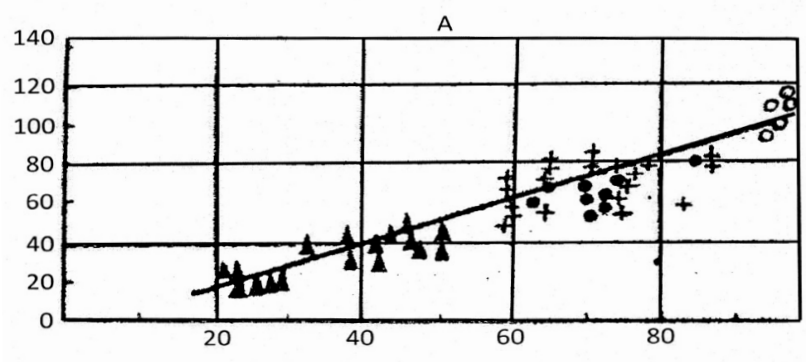

B
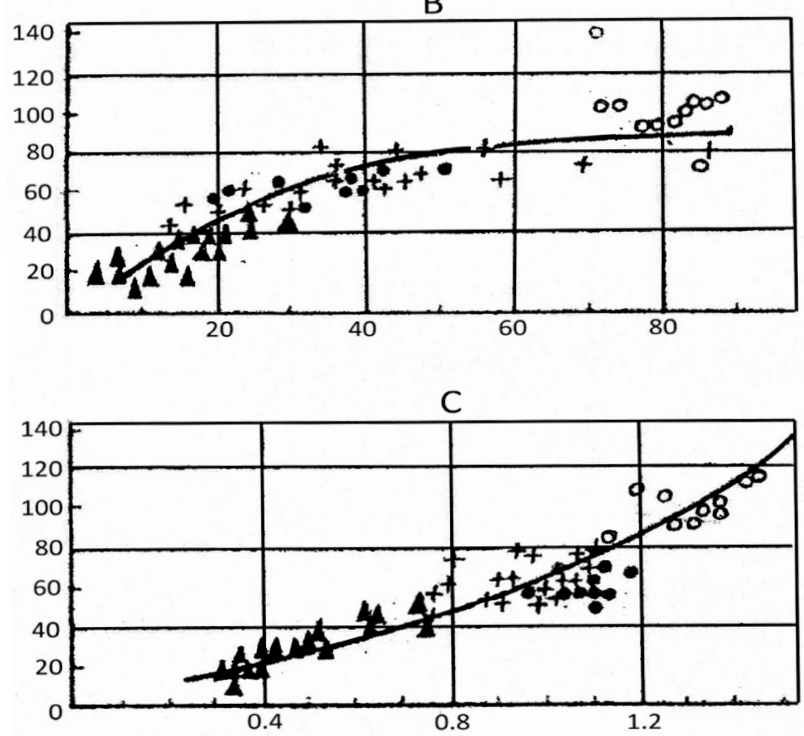

Fig. 3. Changing the indicator of pulmonary ventilation depending on the intensity of metabolic processes during the performance of special exercises of basketball players. Regressions of pulmonary ventilation are presented: $\mathrm{A}$ - by the level of aerobic metabolism

$\left(\mathrm{VO}_{2}, \% \max \right)$; $\mathrm{B}$ - level of anaerobic metabolism $(\mathrm{Ex} \mathrm{CO}, \% \max )$; $\mathrm{C}-$ speed of use of macroerges $(\sim \mathrm{P} / \mathrm{t}, \mathrm{M} / \mathrm{min})$. At the ordinate the level of pulmonary ventilation, $1 / \mathrm{min}$. tion about the current status and capabilities of each athlete in the team (Montgomery, Pyne, \& Minahan, 2010; Sallet, Perrier, Ferret, Vitelli, \& Baverel, 2005).

Interpretation of the received data about the changes in the players' physiological functions in the process of training and competition makes it possible to better understand them (Ben Abdelkrim, El Fazaa, \& El Ati, 2007), Some data on such characteristics have been obtained previously (Ciuti, Marcello, Macis, Onnis, Solinas, \& Lai, 2009; Kozina, Iermakov, Cretu, Kadutskaya, \& Sobyanin, 2017). Considering the above will to some extent help to resolve the question of the possibility of applying the systematization of the physiological criteria of special training means of training basketball players, which was confirmed by other data of our study (Gonzalo-Skok, Tous-Fajardo, Valero-Campo, Berzosa, Bataller, Arjol-Serrano, \& Mendez-Villanueva, 2017; Ramos, Rubio, Martínez, Esteban, \& Jiménez, 2010).

Contributes to the solution of the question of selection of special training aids for the preparation of basketball players for the first time the data obtained on the results of the study of the "distinctive power" of individual physiological indicators. To some extent, these findings confirm the results of the study (Anastasiadis, 2006; Koryagin, Blavt, \& Grebinca, 2016).

According to the results of the analysis of empirical data of the study, the limits of physiological indicators of the distant ranges of training loads of basketball players were established. Identifying such values can be used to control the training process, which is consistent with the ideas outlined in the literature (Crisafulli, Melis, \& Tocco, 2005; Zankovets, 2016).

The result obtained during the control of the physiological features of basketball players was consistent with the information (Thoden, Wilson, \& MacDougall, 1991; Tomlin \& Wenger, 2002) which the consumption of $\mathrm{O}_{2}$ cannot be used when graduation exercises.

The result obtained during the pedagogical control of the physiological features of basketball players, corresponded to information (Kozina, Iermakov, Cretu, Kadutskaya, \& Sobyanin, 2017; Narazaki, Berg, Stergiou, \& Chen, 2009; Sallet, P., Perrier, D., Ferret, J.M., Vitelli, V., \& Baverel, 2005), regarding changes in the parameters of the physiological functions of basketball players during the game.

The results of the study supplement the information on the physiological control of competitive and training activities of basketball players regulating the expediency of training influences to ensure the efficiency of the basketball players' actions (Ciuti, Marcello, Macis, Onnis, Solinas, \& Lai, 2009; Scanlan, Fox, Borges, Tucker, \& Dalbo, 2018; Scanlan, Fox, Borges, Tucker, \& Dalbo, 2018).

\section{Conclusions}

1. In assessing the urgent training effect of special exercises of basketball players, different physiological indicators have different information capacity. Indicators of the rate of cleavage of macroergs in working muscles, the rate of formation of alacticity of $\mathrm{O}_{2}$ debt and the "excess" of $\mathrm{CO}_{2}$ are the most "sensitive" to change of load. Indicators that estimate the intensity of aerobic metabolism $\left(\mathrm{O}_{2}\right.$ consumption level) have more limited "differential power".

2. On the basis of the study of the means and methods of training of basketball players, it is proposed to systematize special exercises by the nature of their training effect: exercise 
of predominantly aerobic effects; exercises of mixed aerobicanaerobic orientation; exercise anaerobic lactate exposure; exercise anaerobic glycolytic orientation.

\section{Conflict of interest}

The authors state no conflict of interest.

\section{References}

Nelsen, R.Jr. (2015). "Progress" in Sport: Are we really surpassing the supermen of the past? Just Fly Sports. https://www.just-fly-sports.com/progress-in-sport

Raiola, G., Altavilla, G., Tafuri, D., \& Lipoma, M. (2016). Analysis of learning a basketball shot. Journal of Physical Education and Sport, 16(1), 3-7. https://doi.org/10.7752/jpes.2016.01001

Doroshenko, E., Sushko, R., Koryahin, V., Pityn, M., Tkalich, J., \& Blavt, O. (2019). The competitive activity structure of highly skilled basketball players on the basis of factor analysis methods. Hum Mov, 20(4), 33-40. https://doi.org/10.5114/hm.2019.85091

Backman, L.J., \& Danielson, P. (2011). Low range of ankle dorsiflexion predisposes for patellar tendinopathy in junior elite basketball players: A 1-year prospective study. American Journal of Sports Medicine, 39(12), 2626-2633. https://doi.org/10.1177/0363546511420552

Hoare, D.G. (2000). Predicting success in junior elite basketball players-the contribution of anthropometic and physiological attributes. Journal Sci Med Sport, 3(4), 391405. https://doi.org/10.1016/s1440-2440(00)80006-7

Gonzalo-Skok, O., Tous-Fajardo, J., Valero-Campo, C., Berzosa, C., Bataller, A.V., Arjol-Serrano, J.L., \& MendezVillanueva, A. (2017). Eccentric overload training in team-sports functional performance: Constant bilateral vertical vs. Variable unilateral multidirectional movements. International Journal of Sports Physiology and Performance, 12(7), 951-958. https://doi.org/10.1123/ijspp.2016-0251

Karpowicz, K., \& Karpowicz, M. (2013). Structure of motor skills in young athletes. Hum Mov, 14(3), 221-228. https://doi.org/10.2478/humo-2013-0027

Asadi, A., Saez de Villarreal, E., \& Arazi, H. (2015). The effects of plyometric type neuromuscular training on postural control performance of male team basketball players. Journal of Strength and Conditioning Research, 29(7), 18701875. https://doi.org/10.1519/JSC.0000000000000832

Ben Abdelkrim, N., Castagna, C., El Fazaa, S., \& El Ati, J. (2010). The effect of players' standard and tactical strategy on game demands in men's basketball. Journal Strength Cond Res, 24, 2652-62. https://doi.org/10.1519/JSC.0b013e3181e2e0a3

Ciuti, C, Marcello, C., Macis, A., Onnis, E., Solinas, R., \& Lai, C. (2009). Improved aerobic power by detraining in basketball players mainly trained for strength. Journal Sports Medicine, Training and Rehabilitation, 6(4), 325335. https://doi.org/10.1080/15438629609512063

Aiken, C.A., Fairbrother, J.T., \& Post, P.G. (2012). The Effects of Self-Controlled Video Feedback on the Learning of a Basketball Set Shot. Frontiers in Psychology, 3, 338. https://doi.org/10.3389/fpsyg.2012.00338

Montgomery, P.G., Pyne, D.B., \& Minahan, C.L. (2010). The physical and physiological demands of basketball training and competition. International Journal of Sports Physiology and Performance, 5, 75-86.

https://doi.org/10.1123/ijspp.5.1.75

Tyshchenko, V., Hnatchuk, Ya., Pasichnyk, V., Bubela, O.O. \& Semeryak, Z. (2018). Factor analysis of indicators of physical and functional preparation of basketball players. Journal of Physical Education and Sport, 18(4), 269, 1839 1844. https://doi.org/10.7752/jpes.2018.s4269

Gonzalo-Skok, O., Sánchez-Sabaté, J., Izquierdo-Lupón, L., \& Sáez de Villarreal, E. (2019). Influence of force-vector and force application plyometric training in young elite basketball players. European Journal of Sport Science, 19(3), 305-314. https://doi.org/10.1080/17461391.2018.1502357

Erčulj, F., Blas, M., \& Bračič, M. (2010). Physical demands on young elite European female basketball players with special reference to speed, agility, explosivestrength, and take-off power. J Strength Cond Res, 24(11), 2970-2978. https://doi.org/10.1519/JSC.0b013e3181e38107

Ben Abdelkrim, N., El Fazaa, S., \& El Ati, J. (2007). Timemotion analysis and physiological data of elite under-19year old basketball players during competition. British Journal Sports Medicine, 41(2), 69-75. https://doi.org/10.1136/bjsm.2006.032318

Conlee, R. K., McGown, C. M., Fisher, A. G., Dalsky, G. P., \& Robinson, K. C. (2017). Physiological Effects of Power Volleyball. The Physician and Sportsmedicine, 10(2), 93-97. https://doi.org/10.1080/00913847.1982.11947167

Anastasiadis, M. (2006). The Basketball Training. Athens: IN Elvekalt EPE.

Sallet, P., Perrier, D., Ferret, J.M., Vitelli, V., \& Baverel, G. (2005). Physiological differences in professional basketball players as a function of playing position and level of play. Journal Sport Med Phys Fit, 45, 291-295.

Tomlin, D., \& Wenger, H. (2002). The relationships between aerobic fitness, power maintenance and oxygen consumption during intense intermittent exercise. Journal of Science and Medicine in Sport, 5(3), 194-203. https://doi.org/10.1016/S1440-2440(02)80004-4

Koryagin, V., \& Blavt, O. (2019). Innovative test control technologies in physical education and sports: a monograph. Lviv, Ukraine: Lviv Polytechnic Publishing House, 236.

Beaver, W.L., Wasserman, K., \& Whipp, B. J. (1986). A new method for detecting anaerobic threshold by gas exchange. J Appl Physiol, 60(6), 2020-7. https://doi.org/10.1152/jappl.1986.60.6.2020

MacDougall, J.D., Wenger, H.A., \& Green, H.J. (2017). In Physiological Testing of the High Performance Athlete, (2nd ed), Champaign: Human Kinetics.

Volkov, N.I. (1986). Biochemical factors of sports performance. M.: FiS.

Zankovets, V. (2016). Testing Encyclopedia. M.: Sport.

Yeager, J.M., \& Karsten, K. (eds.). (2016). Muscles in sports. Anatomy. Physiology. Training. Rehabilitation. M.: Practical medicine.

Ingebrigtsen, J., Jeffreys, I., \& Rodahl, S. (2013). Physical characteristics and abilities of junior elite male and female handball players. J Strength Cond Res, 27(2), 302-309. https://doi.org/10.1519/JSC.0b013e318254899f

Kozina, Z., Iermakov, S., Cretu, M., Kadutskaya, L., \& Sobyanin, F. (2017) Physiological and subjective indicators of reaction to physical load of female basketball players with different game roles. Journal of Physical Education and Sport, 17(1), 56, 378-382. https://doi.org/10.7752/jpes.2017.01056 
Ramos, R., Rubio, J., Martínez, F., Esteban, P., \& Jiménez, J. (2010). Physiological, podological and somatometric characteristics of professional basketball player. Archivos de Medicina del Deporte, 27(136), 84-94.

Koryagin, V., Blavt, O., \& Grebinca, G. (2016). Optimization of the technical training system. Journal of Physical Education and Sport, 16(2), 1029-1030. https://doi.org/10.7752/jpes.2016.s2163

Thoden, J.S., Wilson, B.A., \& MacDougall, J.D. (1991). Testing aerobic power. In: MacDougall JD, Wenger HA, Green HJ (eds) Physiological testing of the elite athlete. Movement, New York, 107-173.

Narazaki, K., Berg, K., Stergiou, N., \& Chen, B. (2009).

Physiological demands of competitive basketball. Scand J Med Sci Sports, 19(3), 425-432.

https://doi.org/10.1111/j.1600-0838.2008.00789.x

Scanlan, A.T., Fox, J.L., Borges, N.R., Tucker, P.S., \& Dalbo, V.J. (2018). Temporal changes in physiological and performance responses across game-specific simulated basketball activity. Journal of Sport and Health Science, 7(2), 176-182. https://doi.org/10.1016/j.jshs.2016.05.002

\title{
ВИЗНАЧЕННЯ ТРЕНУВАЛЬНОГО ЕФЕКТУ СПЕЦІАЛЬНИХ ВПРАВ БАСКЕТБОЛІСТІВ
}

\author{
Віктор Корягін ${ }^{1 \mathrm{ABCD}}$, Оксана Блавт ${ }^{1 \mathrm{ABCD}}$, \\ Володимир Пристинський ${ }^{\text {ABCD }}$, Володимир Стадник ${ }^{1 \mathrm{ABCD}}$
}

\author{
${ }^{1}$ Національний університет «Львівський політехніка» \\ ${ }^{2}$ Державний вищий навчальний заклад «Донбаський державний педагогічний університет» \\ Авторський вклад: А - дизайн дослідження; В - збір даних; C - статаналіз; D - підготовка рукопису; Е - збір коштів \\ Реферат. Стаття: 8 с., 3 рис., 33 джерела.
}

Мета дослідження - виявлення фізіологічних показників для систематизації спеціальних вправ баскетболістів і граничні значення фізіологічних показників 3 достатньою «розрізняльною потужністю», в кожному 3 виділених діапазонів тренувальних навантажень.

Матеріали та методи. У дослідженні було використано емпіричні методи вимірювання частоти серцевих скорочень під час змагань, величини легеневої вентиляції, $\mathrm{O}_{2}$-споживання під час фізичної роботи, $\mathrm{O}_{2}$-боргу, «надлишку» виділення $\mathrm{CO}_{2}$ і окремих пульсових показників, методи математичної статистики.

Результати. Встановлені співвідношення між рівнем фізичного навантаження і фізіологічними зрушеннями в організмі баскетболістів. Виявлено, що показники легеневої вентиляції можуть бути використані для конт- ролю тренувального впливу вправ аеробного характеру. Показано, що найбільш виражений вплив на організм баскетболістів мають вправи анаеробної гліколітичної спрямованості. Певні середні і граничні значення для різних фізіологічних показників, характерних для різних діапазонів тренувальних навантажень.

Висновки. Встановлено, що при оцінці термінового тренувального ефекту спеціальних вправ баскетболістів різні фізіологічні показники володіють різною "розрізняльною потужністю». На основі результатів дослідження, запропонована систематизація спеціальних вправ баскетболістів згідно діапазонів тренувальних навантажень за характером викликаного ними тренувального ефекту.

Ключові слова: спеціальні вправи, баскетболіст, оцінка, тренувальний ефект, розрізняльна потужність.

\section{Information about the authors:}

Koryahin V.: koryahinv@meta.ua; https://orcid.org/0000-0003-1472-4846; Department of Physical Education, Lviv Polytechnic National University, Bandera St, 12, Lviv, 79013, Ukraine.

Blavt O.: oksanablavt@ukr.net; https://orcid.org/0000-0001-5526-9339; Department of Physical Education, Lviv Polytechnic National University, Bandera St, 12, Lviv, 79013, Ukraine.

Prystynskyi V.: v.prystynskyi@hotmail.com; https://orcid.org/0000-0003-1681-3543; Department of Theoretical, Methodological Foundations of Physical Education and Rehabilitation, State Higher Educational Institution "Donbass State Pedagogical University", Batiuka St, 19, Sloviansk, 84116, Ukraine.

Stadnyk V.: vova121212131313@ukr.net; https://orcid.org/0000-0002-2864-4794; Lviv Polytechnic National University, Bandera St, 12, Lviv, 79013, Ukraine.

Cite this article as: Koryahin, V., Blavt, O., Prystynskyi, V., \& Stadnyk, V. (2021). Research of Training Loads of Basketball Players. Teoriâ ta Metodika Fizičnogo Vihovannâ, 21(2), 107-112. https://doi.org/10.17309/tmfv.2021.2.02

Received: 11.01.2021. Accepted: 12.05.2021. Published: 25.06.2021

This work is licensed under a Creative Commons Attribution 4.0 International License (http://creativecommons.org/licenses/by/4.0). 